УДК 17.022.1:821.161.2

https://doi.org/10.31548/philolog2020.02.057

ЦІННІСНІ ОРІЕНТИРИ ТВОРЧОСТІ МАКСИМА РИЛЬСЬКОГО

Т. М. ЧУМАК, кандидат педагогічних наук, старший викладач, Національний університет біоресурсів і природокористування України

E-mail:tchumak27@ukr.net

https://orcid.org/0000-0003-4723-1757

\begin{abstract}
Анотація. У статmі розглядається творчість Максима Рильського як представника української культури XX століття з погляду ціннісних орієнтацій. Обгрунтовано, що світоглядні переконання М. Рильського пов'язані з рядом переломних періодів у житті народу, з долею якого якнайміцніше було пов'язано його життєве призначення. Доведено, що поет і фрілософ Максим Рильський був, $є$ i буде одним із найбільших українських поетів XX століття, діячем культури фрранківського фоормату, що при трагічному творчому скаліченні все ж таки зумів двигнути вперед українську духовність, розвинути нашу мову, наше розуміння природи і людської душі. Творчість Максима Рильського становить вагому сторінку в історії української літератури. Його ім'я входить у всі енциклопедії, антології світового мистецтва. Осмислення творчої спадщини М. Т. Рильського як поета, письменника, публіциста, перекладача знайшло широкий відгомін у дослідженнях літературознавців, фрілологів, письменників, критиків, спеціалістів у галузі перекладу тощо. Багатовікова культурна реальність для М. Рильського була постійним джерелом поетичного натхнення. Своє творче кредо поет висловив у багатьох віршах, головна думка яких - чистота й непідкупність поетичного слова, щирість і чесність. Навіть і в нелегкі для української культури часи М. Рильський зумів написати видатні твори, у яких підносив національну ідею, будив історичну пам'ять свого народу, утверджував думку про його талановитість, національне відродження України, невмирущість рідної мови. Цілком очевидно, що поет і фрілософо Максим Рильський був, $\epsilon i$ буде одним із найбільших українських поетів XX століття, діячем культури фрранківського фрормату, що при трагічному творчому скаліченні все ж таки зумів двигнути вперед українську духовність, розвинути нашу мову, наше розуміння природи і людської душі.

Ключові слова: Максим Рильський, поетична творчість, неокласицизм, творче кредо, історична пам'ять, рідна мова, українська духовність.
\end{abstract}

Актуальність

дослідження.

Українська національна духовність - це історично сорормована система духовних багатств народу, яка відображає найвищі цінності його національної душі, характеру, світогляду, моралі, ідеології, національної самосвідомості. Особистість митця і його творчість не тільки може служити зразком для розуміння українського національного характеру, його внутрішньо-почуттєвої структури, національного світовідчуття й світобачення, а й стати взірцем для наслідування, для формування в читачів відповідних духовних орієнтирів. Українська культура завжди була багатою на таланти. Проте далеко не всі вони відбулися, особливо в XX столітті. Одні змушені були відмовитися від себе й деградували, інші емігрували, ті ж, що залишилися й не вписалися в рамки методу соцреалізму, були жорстоко репресовані. Ці факти загальновідомі й ні в кого не викликають сумніву.

Серед тих нечисленних митців, що й за таких умов зуміли відбутися й дістати світове визнання, є Максим Рильський. Його ім'я входить у всі енциклопедії, антології світового мистецтва. Тому вважаємо за потрібне проаналізувати творчість цього митця з погляду відображення в ній його духовних орієнтирів.

Аналіз досліджень і публікацій. Осмислення творчої спадщини М. Т. Рильського як поета, письменника,

(C) T. М. Чумак

«International journal of philology» | «Міжнародний філологічний часопис» Vol. 11, № 2, 2020 
публіциста, перекладача знайшло широкий відгомін у дослідженнях літературознавців, фрілологів, письменників, критиків, спеціалістів у галузі перекладу тощо. Свої дослідження йому присвятили О. Білецький, Ю. Лавриненко, Є. Маланюк, І. Ільєнко, Л. Новиченко, М. Жулинський, І. Дзюба, Є. Сверстюк, П. Сердюк, В. Панченко, В. Неділько, В. Агеєва та інші. Значною мірою згадані дослідники торкалися питання духовного світу письменника. Проте геній Максима Рильського важко осмислити в одній чи кількох монографріях. Духовні орієнтири творчості митця ще потребують свого вивчення. У пропонованій статті ми зробили тільки часткову спробу узагальнити, на що були спрямовані воля, розум і почуття великого поета й мислителя $\mathrm{XX}$ століття.

Мета дослідження - проаналізувати світоглядні переконання Максима Рильського, відображені в його творчості; визначити, як вони пов'язані з рядом переломних періодів у житті українського народу, з долею якого якнайміцніше було поєднано його життєве призначення.

Результати. Знайти ключ до розуміння світогляду М. Рильського нам допоможе звернення до змісту епохи, у яку він жив і формувався як особистість. Українську ментальність він увібрав у себе від народження, будучи сином звичайної селянки 3 Романівки на Київщині, пізнаючи народні основи життя. Однак, попри сільське дитинство, що дарувало йому відчуття взаємної причетності, спільності з природою, визначальний вплив на характер поета справила батькова шляхетна простота. «Гордість наповнює серце при думці, що я син того Тадея», - напише він згодом. Пишатися справді було чим: батько майбутнього поета, Тадей Розеславович, родовитий шляхтич українського походження, був видатним учениметнографром та економістом, провідним діячем Київської громади - українського культурно-просвітнього товариства кінця XIX ст., до якого входили історик В. Антонович, композитор М. Лисенко, літератор М. Старицький, мовознавці П. Житецький, К. Михальчук. Тому творчість письменника відбиває ідеали, прагнення, дух народу, нації.

Подальші світоглядні переконання М. Рильського пов'язані з рядом переломних періодів у житті народу, з долею якого якнайміцніше було пов'язано його життєве призначення. Уже перша збірка «На білих островах», написана в досить юному віці, засвідчила появу дужого таланту. На загальному інтимно-ліричному тлі, притаманному всім молодим поетам, були й серйозні роздуми про суть життя, про нужденну дійсність, про людський труд і красу природи. «Із молодих ліриків багато надій подає свіжий талант М. Рильського, зазначала в огляді сучасної української лірики Софрія Русова. - Пройняті щирим почуттям молодого серця, милозвучні й вишукані формою... речі в цьому збірнику виявляють незаперечний ліричний талант» [1, с. 75].

Кожна культурно-історична епоха виробляє власні уявлення про статус і призначення митця, про його роль у житті суспільства. Наприкінці XIX ст. бунтарімодерністи доклали максимум зусиль, аби зруйнувати узвичаєні стереотипи, образити смак пересічного обивателя-читача. Що справді не могли прийняти прихильники старого доброго реалізму, то це небажання використовувати мистецтво як засіб у політичній боротьбі, підпорядковувати його якимось ідеологічним завданням i потребам [2, с. 15].

Тим часом виходять нові книги Рильського, які знаменують вже нову, зовсім не «учнівську», добу в його творчості: «На узліссі» - «ідилія, октавами писана» (1918), два видання збірки «Під осінніми зорями» (1918 і 1926), «Синя далечінь» (1922), «Крізь бурю й сніг» (1925), «Тринадцята весна» (1926), «Гомін і відгомін», «Де сходяться дороги» (обидві 1929). Саме ці книги становлять, на думку дослідників, основу поетичного «неокласицизму» митця.

Сам Рильський на питання, хто такі «неокласики», відповідав так:

« - А хто такі класики, знаєте? ...Це

(C) T. М. Чумак

«International journal of philology» | «Міжнародний філологічний часопис» Vol. 11, № 2, 2020 
ті, що створили невмирущі твори. «Нео» - новий. Неокласики - нові класики. Але ця назва дана на глум, самі поети, що їх названо неокласиками, ніколи себе так не називали. Але вони вважають себе учнями, послідовниками тих, що становлять славу і гордість людства, - учнями класиків. Вони намагаються кращі надбання світової культури перенести на український ґрунт, прищепити їй пагони класичної спадщини» [1, с. 75]. «Неокласиками» іменували неформальне об'єднання українських письменників і критиків 20-х років, до якого належали, зосібна, Микола Зеров (духовний лідер гурту, його програмний голова), Павло Филипович, Михайло Драй-Хмара, Освальд Бургардт (Юрій Клен), Віктор Петров (прозаїк В. Домонтович), Михайло Могилянський та деякі інші. Перші четверо разом із Рильським становили славетне «гроно п'ятірне нездоланих співців», яке наважилося зоставатися собою в добу цілковитого знеособлення цілих «ешелонів» літературних (та й не тільки!) сил. Переосмисливши творчу спадщину минулих поколінь, молоді поети початку XX віку взяли курс на вивчення власної літературної та культурної історії. Зокрема, М.Зеров у літературній дискусії 1925-28 рр. у статті з прикметною назвою «Ad fontes» (лат. - до джерел) наголошує: «Гадаю, що для розвитку нашої літератури потрібні три речі: 1. Засвоєння величного досвіду всесвітнього письменства, тобто хороша літературна освіта письменника і вперта систематична робота коло перекладів. 2. Вияснення нашої української традиції і переоцінка нашого літературного надбання... 3. Мистецька вибагливість, підвищення технічних вимог до початкуючих письменників» [3, с. 439].

Ці вимоги, цілком тверезі і слушні 3 погляду здорового глузду, ідейні опоненти Зерова і його однодумців розцінили як контрреволюційні. «Неокласики» не висували жодної офріційної «платформи». Та й стосовно стильового плану їх творчі напрацювання були досить різними: тільки у М. Зерова, як згодом зауважував Юрій Шерех, переважав «чистий» неокласицизм, решта ж поетів схилялися то до символізму, то до неоромантизму, керуючись, однак, чіткою настановою на повновартісне, політично незаанґажоване мистецтво. Саме в цьому шляхетному, проте засуджуваному й переслідуваному товаристві й перебував наш поет у пору свого найвищого творчого розквіту. Багатовікова культурна реальність для М. Рильського була постійним джерелом поетичного натхнення. У нього безліч «вічних супутників», «співрозмовників». Книжковий світ для нього - «не кабінетна схоластика, а жива, багатоголоса й багатолика, витворена фантазією, дійсність» [4, с. 8]. Поетична творчість Рильського тих часів позбавлена будьяких ідеологічних нашарувань. Натомість визначальними в ній $€$ моральні та естетичні закони й критерії. Своє творче кредо поет висловив у багатьох віршах, головна думка яких - чистота й непідкупність поетичного слова, щирість і чесність:

Учися чистоти і простоти

I, стоптуючи килим золотий,

Забудь про вежі темної гордині («Запахла осінь в'ялим тютюном...»).

Ці рядки звучать і як напутнє слово собі, і як заповіт нащадкам. Кожному письменнику властиво розмірковувати про роль своєї творчості, про своє призначення в складному світі людських почуттів і взаємин, про завдання поетичного слова. Свої міркування Максим Рильський підносить на якісно новий щабель, одухотворяючи природу й беручи іï за основу, за джерело поетичного натхнення, творчої наснаги, шукаючи в ній істину й першопричину буття:

Але любить чи не любити те,

Що вколо нас і в нас самих росте,

Що творить нас, що творимо самі ми, Лише сліпець, що замість крові в нім Тече чорнило струменем неживим,

Тривожиться питаннями такими (3 циклу «Сад серед пустелі», 1927-29). 
«Революції не запримітив...», - так іронічно-стисло окреслив громадянську й творчу позицію Максима Рильського в той період його добрий товариш, незрівнянний гуморист Остап Вишня. Не могли талановитого поета не вражати події драматичного звучання, однак самою природою свого обдарування він був відокремлений від них. Зло не подолати злом, натомість від нього можна дистанціюватися, керуючись власним моральним вибором. Між роллю діячареформатора, упевненого у своїй грандіозній місії покращити світ, - i вдячного спостерігача, сповненого довіри до досконалості Божого творіння, поет без вагань обирає останню.

«Коли звернемось до моїх речей, писав митець у 1923 р., відповідаючи на закиди тогочасної заідеологізованої критики, - то справді дивно читати в 1922/23 рр. про рибальство, спокій і т. п. Це не значить, проте, що я весь час революції лише спокійно ловив рибу, а тільки вказує на одну особливість моєї психології: я можу одгукуватись ліричним віршем тільки на минуле, на те, що «одстоялось» у душі і може мати прозору форму, питому моїй манері. Інакше писати не можу» [5, с. 24].

Тож закиди в асоціальності, які переслідували поета протягом чи не всього свідомого життя, а особливо в 20ті роки, водночас і точні й безпідставні. Точні, бо таки справді Рильський прагнув бути далі від соціальних метаморфоз, воліючи плекати власний сад, а не вирубувати «до основанья» чужі сади, щоб «а затем», як співалося в «Інтернаціоналі», - на випаленому зрубі прищепити «нове» життя. Нi, не час із його марнотною всепроминальністю цікавив його насамперед, а вічність навіть відкарбована в одній-єдиній миті, немовби застиглій у своїй самоцінній суті. Він творив не «на злобу», а на добро - тому й шукав у кожній миті непроминального. Між традицією i революцією митець обирав традицію.

Рильський - поет живої вічності, рухомого спокою, світлого суму. Він умів віднайти гармонію між протилежними началами, врівноважити їх в органічному синтезі. I прагнення точного слова й строгої форми, «неокласичної» ясності природно доповнювалося символістською настановою на зумисну недомовленість, прихованість багато-шарового сенсу за серпанком слова:

Не показать, а заховать я хочу

В моїх словах душі моєї світ,

Моїх бажань чутливість півжіночу

І рідних душ надзоряний привіт.

Не сяєвом, а димом фріалковим

У присмерковій музиці зітхань

Я пропливу незрозумілим словом

За дальню грань.

І випливу із життєвого лісу,

Де навіть Данте мудрий заблудив.

I гляну за останнюю завісу,

І заспіваю - та уже без слів. («Під осінніми зорями», 1926).

Замолоду Рильський був фрілософромекзистенціалістом, його лякали соціальні й національні межі людського духу. Він сприймав людину цілісно з її фрізичними й душевними болями, але бачив, що поза межами цих почувань існує безмір буття, де природа, краса, мистецтво, культура, взаємини між людьми й націями, моральна етика і т. д. відіграють визначну роль у радощах і смутках людини. Рильський розумів, що «неможливо любити небеса, де нема Бога, неможливо й жити на землі без диявола» [6, с. 1]. «...3 розкритими очима На спокійних терезах» прагнув зважувати поет праведне й грішне, прекрасне й потворне. Та, на жаль, не вдалося йому втримати незворушними свої чарівні терези серед ураганів доби.

Уночі налетіли вони -

Чорний вихор у чорному світі, -

І заплакали дочки й сини,

що батьки їх, батьки їх убиті.

[...]

Чорний вихор, незнаного жах,

Недобиті, розбиті святині...

...Із нелюдським смичком у руках

Флорентійських ночей Паганіні. («Музика», 1926).

Так писав митець за п'ять років до власного арешту, по-фрілософрськи 
передчуваючи трагедію української культури в безодні більшовицького терору. Та ось уже «чорний вихор, незнаного жах» постукав і в двері самого поета: 19 березня 1931 р., коли Максим Тадейович збирався святкувати свій день народження, його забрали до Лук'янівської в'язниці. Удома чекали гості, дружина і щойно народжений син - первісток Богдан. «Органи» «чистили» нового «класового ворога». Його звинувачували в причетності до контрреволюційної організації - Спілки визволення України, яку самі ж кати й вигадали, щоб винищити «незгодних» 3 «єдиноправильною політикою партії». Моральні екзекуції тривали майже півроку, і тільки 19 серпня того ж таки 1931-го Рильського було звільнено з-під варти «за відсутністю достатніх доказів злочину». Нам сьогодні досить складно уявити весь трагізм того нагального зламу, тієї болісної травми, яку пережило модерністське покоління на початку 30-х. Невротична бадьорість і казенний безальтернативний оптимізм радянського соціалістичного реалізму були тоді безнадійною, фральшивою протилежністю суворій екзистенціалістській правді. Поет зібрався на силі - й примусив себе написати відверто кон'юнктурні твори, котрі й склали «перебудовчу» книгу «Знак терезів». Це була зовнішня мімікрія, яка не могла не зачіпати, проте, й внутрішнього світу особистості. «Через сидіння у в'язниці, через роки злиднів, голоду, «ізгойства» лежав для Рильського шлях від «Синьої далечини» до уніфрікованої літератури, од «неокласицизму» до радянської стандартизації особи й творчости, - 3 болем констатував «шостий у гроні» неокласиків Віктор Петров [7, с. 47].

«Нечесне ламання таланту», котре якось ненароком 3 острахом згадав був Тичина в одному 3 виступів 1936 р., торкнулося i Максима Рильського. Для нього, як і для інших «могікан» Розстріляного відродження, це був чи не єдиний спосіб виживання, фрізичного самозбереження. Знову ж таки - до честі поета, треба сказати, що він «тримався» набагато міцніше за інших. Йому вдалося зоставатися собою чи не найдовше. Завдяки природній стриманості натури, він зумів зберегти значно більшу цілісність духу, аніж, наприклад, Тичина чи Сосюра. Рильський із його в-собі-врівноваженою самодостатністю, поміркованою відстороненістю від марнотного світу, фрілософічним спокоєм (і не тільки в саду чи над вудками, але й посеред міського гамору) набагато легше пережив випробування епохою, аніж його відчайдушнорозхристані, по-дитячому довірливі й многонадійні ровесники.

Не можемо, на жаль, стверджувати, що поет цілком уникнув внутрішнього роздвоєння, безболісно переніс драму творчого ламання, «сухим» вийшов 3 кривавої «води» сталінського терору. Як і решта «останніх 3 могікан», він сповна випив чашу 3 горем, і роки творчого самообмеження, зрозуміло, не минули безслідно для його поезії [7, с. 47]. Прагматичний i жорстокий механізм імперської культури придушував індивідуальне естетичне чуття художника, ламав його самобутнє світобачення. Однак ті неминучі втрати, яких зазнав талант Рильського внаслідок адаптації до «межової ситуації» «буття у пеклі», були значно меншими, аніж у багатьох інших його побратимів. На думку Євгена Маланюка, навіть його відверто публіцистичні агітки у художньому відношенні набагато досконаліші, ніж аналогічні силувані витвори інших поетів. Одначе страх $є$ страх і біль $є$ біль; якою б силою духу і внутрішньою рівновагою не володіла людина, розгойдані терези доби хоч-не-хоч ранять ії в серце. Особливо коли гинуть найближчі. Саме так сталося з Рильським: через чотири роки після його арешту були ув'язнені інші «лебеді»: М. Зеров, П. Филипович, М. Драй-Хмара (О. Бургардт устиг повернутися на етнічну Батьківщину, Німеччину). За кілька років нікого з них уже не було серед живих: всі троє були замордовані в таборах. Автор «Синьої далечини» мусив із цим жити ще три десятиліття...

Мабуть, найглибше зрозумів і душу, i

() T. М. Чумак

«International journal of philology» | «Міжнародний філологічний часопис» Vol. 11, № 2, 2020 
творчість Максима Рильського, його видатну роль в історії української літератури та культури Євген Маланюк: «Історичну ролю закладника нашої культури й нашої духовности... Максим Рильський виконував як свій твердий національний обов'язок, ніс, як свою невблаганну долю: гідно і неослабно до кінця» [8, с. 328].

I справді, М. Рильський після славословій писав черговий видатний твір, у якому підносив національну ідею, будив історичну пам'ять свого народу, утверджував думку про його талановитість, національне відродження України, невмирущість рідної мови. Як талант, як особистість, як мученик поет не вмер ні 1922-го, ні 1932-го року. Його врятувала любов до природи, до мистецтва, до України. Він прийняв правила гри 3 ворогом, за якими кожен відступ переходив у наступ, служба ворогові переходила в слугування своїм ідеалам, у боротьбу за честь і людську гідність:

І я скажу: «Життєву путь свою

Нерівно і хитаючись, верстав я,

І чашу мук за те належно п'ю.

Але ніколи чорного безслав'я

Я не доходив - утопить свій дар

У чорній лжі; ніколи не впадав я

У себелюбства хворобливий чар... («Мандрівка в молодість»).

Коли почалася Друга світова, Рильський не стояв осторонь вселенських подій; тим паче перейнявся він ними, коли докотилися вони до «ясних зір і тихих вод» його Батьківщини. Доти, за спостереженнями дослідників, у його творчості тема Вітчизни не посідала настільки важливого місця. Та тут поет уже стриматись не міг, i любов до рідної землі, столоченої солдатськими чобітьми, вихлюпнула на папір.

Мати-Україна - центральний, ключовий образ поетичних збірок воєнних літ: «За рідну землю» (1941), «Світла зброя», «Слово про рідну матір», «Світова зоря» (усі три - 1942), «Велика година» (1943), поем «Жага» (1943), «Неопалима купина» (1944). Самі назви цих книг промовляють про їх зміст і пафос. Та розплата за благословення рідній землі не забарилася: щойно завершилася Друга світова війна, і режим знову «натягнув віжки»: 1947-го року 3 ініціативи україножера Лазаря Кагановича у радянській пресі розгорнулася нова «кампанія» 3 цьку-вання тих, хто аж надто сильно переймався долею i втратами однієї 3 республік «Союза нерушимого». Вкотре стріли звинувачень в українському буржуазному націоналізмі посипалися на Юрія Яновського, Івана Сенченка... I - Максима Рильського. «Антинародний», «чужий», «ворожий» фрразеологія режиму не мінялася. Просто риси ці знаходили в нових творах - i зовсім не важило, чи справді вони там $є$. Рильський не пручався надто сильно але й не падав надто низько. Поет знав ціну собі і своїй праці. Він багато зробив, та ще більше - хотів створити. Його талантові судилося розквітнути іще раз пізнім цвітом голосіївської осені. Навіть у межах соцреалізму митець створив цілісну органічну збірку «Голосіївська осінь» (1956). Уперше за багато років тут поет «відчинив двері» таким настроям, як туга, моральний неспокій і тривога, жаль за минулим. Ще 1945 року була написана «Медитація» - 3 тим самим мотивом туги та жалю. Рішуче відкидаючи тон моралізаторства, літній співбесідник ділиться з молодим зачинателем нового життєвого шляху не здобутими успіхами, а прикрими своїми помилками: він пізно збагнув швидкоплинність і неоднозначність часу, кожна хвилина якого - то насіння для добрих квітів і лихого зілля, кожна мить неповторна, одна-єдина, i вдруге ії мелодій, ліній, барв «ми довіку назад не вернемо...». Тому дружні поради й застереження поета, його теплі напучення юнакові на життєву дорогу наче пропущені крізь власні щемливі тривоги, спогади, роздуми, неприховано довірливі, як на сповіді:

Маю жаль я за всім, що плило біля мене й круг мене, любив.

За всіма, що любили мене і кого я

Знай, що в світі найтяжче - це серце

(C) T. М. Чумак

«International journal of philology» | «Міжнародний філологічний часопис» Vol. 11, № 2, 2020 
носити студене!

Краще вже хай шалене, повите у ніжність і гнів («Медитація»).

Передбачаючи його "третє цвітіння», ще 1953 року $€$. Маланюк писав: «...без сумніву, будуть речі в найбільш «замовлених» книжках Максима Рильського, що напевно переживуть і совєтський режим, i московську імперію, бо культурні фракти залишаються, незалежно від умовин, серед яких повстають» [8, с. 328].

Весною 1959 року, коли почався новий наступ на українську мову, коли Москва підкинула нам новий закон, за яким українським батькам надавалося право вибирати для своїх дітей школу з рідною або російською мовою навчання, тобто було вдарено наш народ у саме серце Рильський виступив 3 віршем «Рідна мова». Він прочитав його замість промови на з"їзді письменників.

Як гул століть, як шум віків,

Як бурі подих, рідна мова,

Вишневих ніжність пелюстків,

Сурма походу світанкова,

Неволі стогін, волі спів,

Життя духовного основа.

Цареві блазні і кати,

Раби на розум і на вдачу,

В ярмо хотіли запрягти

її, як дух степів, гарячу,

І осліпити, й повести мова»).

На чорні торжища, незрячу... («Рідна

Рильський говорив про минулі злигодні української мови, але молоді письменники, що фрормувалися тоді як нова, непокірна, опозиційна до русифікації України духовна сила, стоячи аплодували йому і розуміли, що «раби на розум і на вдачу» - це якраз

\section{Список використаних джерел}

1. Ільєнко І. Жага. Труди і дні Максима Рильського: Документальний життєпис. Київ: «Дніпро», 1995. 413 с.

2. Агеєва Віра. Мистецтво рівноваги: Максим Рильський на ті епохи. Київ: Книга, 2012. 392 c.

3. Зеров М. Виступ на диспуті «Шляхи розвитку сучасної літератури» / Українське оті партійні погоничі, секретарі ЦК компартії, що сиділи в президії з"їзду і також аплодували, але не за вище наведені строфри, а за слова про Леніна, який начебто всім «язикам» дав свободу.

I в найтяжчі дні натиску 3 боку партійних вождів та цензури Рильський рятувався любов'ю до України, до ії природи, до людини.

Нехай не виє самотина,

Як дикий пес за ворітьми!

Скажи крізь муку: я людина!

Скажи крізь горе: я $з$ людьми! (1952р.)

Цілком очевидно, що поет і фрілософ Максим Рильський був, $є$ і буде одним із найбільших українських поетів XX століття, діячем культури фрранківського фрормату, що при трагічному творчому скаліченні все ж таки зумів двигнути вперед українську духовність, розвинути нашу мову, наше розуміння природи і людської душі.

Для кожного народу найдорожчою $є$ спадкоємність, безперервність культурної, фрілософрської, релігійної, а звідси й політично-державницької традиції. Заслуга Рильського, крім усього іншого, в тому, що він налагодив i витримав зв'язок між генераціями будівників Української Народної Республіки і будівниками сучасної незалежної України.

Підсумкова книжка-спогад Максима Рильського не могла бути написаною, бо вона вимагала б ревізії всього радянського баласту в його творчості. Така книжка мусила б з усією очевидністю виявити, що автор ії̈ ніколи - на щастя! - не став еталонним радянським поетом [2, с. 391]. І якраз ота збережена - попри все! нерадянськість і дозволила Рильському зоставатися митцем, хай не вповні, але все ж зреалізувати своє велике обдарування.

письменство. Київ: Основи, 2003. 480 с.

4. Панченко В. Від «Білих островів» до «Знака терезів» (Поезія Максима Рильського 1910 - 1932 рр.) / Слово і Час, 2006. № 1. С. 3 - 14.

5. Рильський Б. Мандрівка в молодість батька. Київ: «Молодь», 1995. 124 с.

6. Павличко Д. Мука чистоти: Літературна Україна, 2006, № 24. 12 с.

«International journal of philology» | «Міжнародний філологічний часопис» Vol. 11, № 2, 2020 
7. Тихолоз Б. У саду Максима Рильського / Усе для школи. Київ: «Всеувито», 2001. $80 \mathrm{c}$.

8. Маланюк $€$. Над могилою Максима Рильського: Земна мадонна. Братислава - Лондон, 1991. 470 с.

\section{References}

1. llienko, I. (1995). Zhaha. Trudy i dni Maksyma Ryl's'koho: Dokumentalnyy zhyttyepys [Longing. Works and days of Maksym Rylsky: documentary biography]. Kyiv: Dnipro, 413.

2. Aheieva, V. (2012). Mystetstvo rivnovahy: Maksym Ryl's'kyy na ti epokhy [The art of balance: Maksym Rylsky in those epochs]. Kyiv: Knyha, 392.

3. Zerov, M. (2003). Vystup na dysputi "Shlyakhy rozvytku suchasnoyi literatury" [Speech at the debate The Ways of the Development of Contemporary Literature]. The Ukrainian writing. Kyiv: Osnovy, 480.
4. Panchenko, V. (2006). Vid "Bilykh ostroviv" do "Znaka tereziv" (Poeziya Maksyma Ryl's'koho 1910 - 1932 rr.) [From White Islands to the Sign of Libra (The poetry of Maksym Rylsky in 1910 - 1932)]. Slovo i Chas, Issue 1, 3 - 14.

5. Rylsky, B. (1995). Mandrivka v molodist' bat'ka [The journey to father's youth]. Kyiv: Molod, 124.

6. Pavlychko, D. (2006). Muka chystoty [The agony of purity]. Literary Ukraine, Issue 24, 12.

7. Tykholoz, B. (2001). U sadu Maksyma Pyl's'koho [In the garden of Maksym Rylsky]. All for school. Kyiv: Vseuvyto, 80.

8. Malaniuk, Ye. (1991). Nad mohyloyu Maksyma Ryl's'koho: Zemna madonna [Above the grave of Maksym Rylsky. Earth Madonna]. Bratislava, London, 470.

\title{
VALUABLE REFERENCE POINTS IN THE WORKS OF MAKSYM RYLSKY T. M. Chumak
}

\begin{abstract}
The works of Maksym Rylsky are very significant in the history of Ukrainian literature. His name is mentioned in different encyclopedias and in the antology of the world art. Understanding of the creative heritage of Rylsky as a poet, writer, publicist, translator has found widespread echo in the studies of literary scholars, philologists, writers, critics, translation specialists, etc. The creativity of the writer reflects the ideals, aspirations, spirit of the people and the nation. The first collection On White Islands, which was written in pretty young age, stated the appearance of the strong talent. According to the researches, new books of Rylsky are the basis of his poetic "neoclassicism." The centuries-old cultural reality for Rylsky was a constant source of poetic inspiration. He expressed his creative credo in lots of poems, the main point of which was the purity and probity of a poetic word, sincerity and honesty. However, in 1931, when Maksym Rylsky survived the arrest and pressure of the Soviet system, he had to force himself to write openly conformist works that were included in the book The Sign of Libra. The pragmatic and cruel mechanism of imperial culture suppressed the individual aesthetic sense of the artist, breaking his original worldview. However, in these difficult times for Ukrainian culture Rylsky managed to write outstanding works in which he presented the national idea, awakened the historical memory of his people, affirmed the idea of his talent, national re generation of Ukraine, the immortality of his native language. $t$ is obvious that the poet and philosopher Maksym Rylsky was, is and will be one of the greatest Ukrainian poets of the twentieth century. He was an activist of the Franko's format culture, which, in the event of a tragic creative defacement, was still able to move Ukrainian spirituality forward, to develop our language, our understanding of nature and the human soul.
\end{abstract}

Keywords: Maksym Rylsky, poetry writing, neoclassicism, creative credo, historical memory, mother tongue, Ukrainian spirituality.

\section{(C) T. М. Чумак}

«International journal of philology» | «Міжнародний філологічний часопис» Vol. 11, № 2, 2020 